1986

\title{
First Nations Self-Government in Canada
}

Peter A. Cumming

Osgoode Hall Law School of York University

Diana Ginn

Source Publication:

Nordic Journal of International Law. Volume 55, Issues 1-2 (1986), p. 86-116.

Follow this and additional works at: https://digitalcommons.osgoode.yorku.ca/scholarly_works (c) (i) $\ominus$

This work is licensed under a Creative Commons Attribution-Noncommercial-No Derivative Works 4.0 License.

\section{Recommended Citation}

Cumming, Peter A., and Diana Ginn. "First Nations Self-Government in Canada." Nordic Journal of International Law 55.1-2 (1986): 86-116.

This Article is brought to you for free and open access by the Faculty Scholarship at Osgoode Digital Commons. It has been accepted for inclusion in Articles \& Book Chapters by an authorized administrator of Osgoode Digital Commons. 


\title{
First Nations Self-Government in Canada
}

\author{
By Peter A. Cumming and Diana Ginn.
}

\section{The concept of self-government}

The terms "self-government « and »self-determination« when used in the context of native peoples' government, have a broad range of meanings and are often used without precision. For the purposes of our discussion, two fundamentally different concepts must be distinguished.

First, native peoples in Canada, as with all Canadian citizens, have the rights of citizenship and provincial residency, to participate in the federal and provincial institutions of government within Canada, a federal state. In addition, Indian peoples living on reserves have the right to participate in band council elections and government, as provided in the Indian Act. As federal legislation, the Indian Act's provisions are, of course, entirely dependent upon the wishes of Parliament. Thus, Indian local government provided by the Indian Act, is analogous, in so far as its basis, to municipal governments constituted under the authorizing legislation of the various provincial legislatures. Any such governments have delegated and dependent powers, and can be conveniently referred to under the generic term of »Indian municipal government «.

Bill C-52, which died on the order paper after first reading June 27, 1984, of the 2nd Session, 32nd Parliament, provided in section 1 that it might be cited as the $»$ Indian Self-Government Act « and provided in section 3 that an $» I n d i a n$ Nation « (defined by section 2 to mean one or more bands, or any other Indian community) might "seek recognition «, but all powers conferred upon such Indian Nations would have derived from the legislation itself, and be subject to the possibilities of amendment and repeal. Thus, while Bill C-52 would have provided much more latitude for local decision-making than is seen with the relatively more paternatlistic Indian Act regime, both forms of government are in concept and status smunicipal selfgovernments«.

The second concept or basis of government arises through having sovereign powers. Thus, under the sovereign allocation of powers provided by the Canadian Constitution., both Parliament and the ten provinces have certain legislative powers. Neither level of government can encroach upon the legislative authority of the other, and subject to constitutional amendment, the authority to legislate within their respective spheres of legislative competence is absolute. This form of government can be said to constitute "sovereign « self-government.

For native peoples, the concept of full self-government is closely related to theories of sovereignty and inherent rights. Nationhood and government have been described as "manifestations «(1) of sovereignty, which represents the authority exercised as of right by a state over its people and territory.(2) An inherent power is one which flows from the existence of a sovereign state and is not delegated or given by any other government.(3) The inherent jurisdiction of a self-governing nation includes the right to define its own form of government and its membership; to regulate land use and ownership, and the domestic affairs of its members; to exclude people from its territory; and to enforce and administer its laws.(4) For Indians, self-government is also sinextricably linked to the achievement of self-determination and the preservation of the Indian cultural heritage«.(5) 
It has been argued that a community's right to self-determination should be recognized if it was formerly an independent nation, or part of a nation, with its own tribal organization, and if the community still exists as a group which has not been assimilated into the dominant society.(6)

Before contact with Europeans, the Indians of North America formed sovereign nations (7), each with a style of government developed to meet the needs of the particular nation. Some of the political systems, for instance, that of the Iroquois, were quite complex.(8) Many Indians do not regard themselves as having relinquished their sovereignty; in fact, they view the Royal Proclamation of 1763 (9) and the treaties as recognizing Indian sovereignty.(10) Section 91(24) of the Constitution Act, 1867 (11), which gives the federal government jurisdiction over $\gg$ Indians and lands reserved for Indians «, is seen as giving the federal government the responsibility of »honoring and protecting«(12) the agreements made between the Crown and Indian nations.

Section 35 of the Constitution Act, 1982 is also seen as confirmation of the right to self-government by those who view Indian self-government as an aboriginal right.

Section 351 ) states that the "existing aboriginal and treaty rights of the aboriginal peoples of Canada are hereby recognized and affirmed«. Obviously, however, the phrase »existing aboriginal and treaty rights « could be interpreted in a number of different ways. There are those who view section 351 ) as practically meaningless, while others argue that it encompasses a full range of rights. Attempts to clarify this section have been made at the three constitutional conferences on aboriginal issues which have been held since the patriation of the Constitution in 1982.

\section{Constitutional Conferences.}

Section 37 of the Constitution Act, 1982 provided that, within a year of the Act coming into force, a conference was to be held to discuss:

Matters that directly affect the aboriginal peoples of Canada, including the identification and definition of the rights of those peoples to be included in the Constitution of Canada.

In preparation for the 1983 conference, Prime Minister Trudeau met in June of 1982 with representatives from the Assembly of First Nations, the Native Council of Canada, and the Inuit Committee on National Issues.(13) (Representatives of the newly formed Metis National Council were later invited to conference). In the fall of 1982 , two working groups were established, one to deal with political and legal issues (including self-government), and the other to focus on economic, social and cultural rights.(14)

The conference, held on March 15 and 16, 1983, lead to the signing of an accord by the four native organizations, the federal government, nine provinces, and the two territories. Quebec did not sign.

Although a significant constitutional amendment on equality (15) was agreed upon, little was accomplished in the area of self-government. To a large extent, the 1983 accord was a recognition of the fact that most of the topics on the agenda had not been dealt with fully and that further discussion was needed. Thus, the accord provided that another constitutional conference was to be held within one year, with an agenda which would include those items not fully considered at the 1983 conference. (16)

In accordance with the 1983 agreement, a second constitutional conference was held on March 8 and 9,1984 . Some months before the conference, working groups 
were again established to deal with a number of topics, including aboriginal selfgovernment.

In his opening remarks at the conference, Prime Minister Trudeau stated: "There is nothing revolutionary or threatening about the prospect of aboriginal selfgovernment. Aboriginal communities have rightful aspirations to have more say in the management of their affairs, to exercise more responsibility for discussions affecting them ...... The Government of Canada remains committed to the establishment of aboriginal self-government and it is my impression that the provinces are very much of the same mind. And so, we are not here to consider whether there should be institutions of self-government, but how these institutions should be brought into being; what should be their jurisdictions, their powers; how they should fit into the interlocking system of jurisdictions by which Canada is governed.«(17)

Prime Minister Trudeau later proposed a constitutional amendment, to the effect that the saboriginal peoples of Canada have the right to self-governing constitutions«(18), however, the nature, jurisdiction and fiscal arrangements of these institutions would have to be defined through negotiations with federal and provincial governments. This proposal did not receive much provincial support, and therefore had to be dropped. (19) The Assembly of First Nations then approached the Prime Minister with the suggestion that a unilateral amendment be brought in Parliament. Prime Minister Trudeau indicated that he would be willing to consider this only if the wording of the federal proposal were left unchanged, and if all four of the native organizations at the conference agreed with the A.F.N.'s suggestion. No such consensus could be reached among the four groups. (20)

At the 1984 conference, it was agreed that another conference would be held the following year. This third First Ministers Conference on Aboriginal issues took place on the second and third of April, 1985. Prime Minister Mulroney opened the conference by urging support for a proposed "Accord Relating to the Aboriginal Peoples of Canada" prepared by the federal government. (21)

The federal proposal began with a general statement:

Whereas the aboriginal peoples of Canada, being descendants of the first inhabitants of Canada, are unique peoples in Canada enjoying the rights that flow from their status as aboriginal peoples, from treaties and from land claims agreements, as well as rights flowing from Canadian citizenship, and it is fitting that

(a) there be protection of rights of aboriginal peoples in the Constitution of Canada,

(b) they have the opportunity to have self-government arrangements to meet their special circumstances as well as the opportunity to exercise their full rights as citizens of Canada and residents of the provinces and territories, and

(c) they have the freedom to live in accordance with their own cultural heritage and to use and maintain their distinct languages; (22).

The accord then provided for an amendment to the Constitution, to recognize and affirm the rights of the aboriginal peoples of Canada to selfgovernment within the Canadian federation, where those rights are set out in negotiated agreements...(23)

The Constitution would also be amended to include a commitment by the federal and provincial governments to participate in negotiating

with representatives of aboriginal people living in particular communities or regions, agreements relating to self-government that are appropriate to the particular circumstances of these people.(24) 
The federal accord proposed that agreements dealing with self-government could provide for a variety of arrangements including ethnic-based government, public government, modifications to existing governmental structures to accomodate the unique circumstances of the aboriginal peoples of Canada and management of, and involvement in, the delivery of programs and services. (25)

A number of specific matters relating to self-government which could be addressed in negotiation of an agreement were also set out in the federal proposal. These included

(a) Membership in the group of aboriginal people concerned;

(b) the nature and powers of the institutions of self-government;

(c) responsibilities of, and programs and services to be provided by, the institutions of self-government;

(d) the definition of the geopgraphic areas over which the institutions of selfgovernment will have jurisdiction;

(e) resources to which the institutions of self-government will have access;

(f) fiscal arrangements and other bases of economic support for the institutions of self-government; and

(g) distinct rights for the aboriginal people concerned.(26)

The federal government also seemed amenable to a constitutional amendment which could prohibit agreements signed by the federal and provincial governments, and aboriginal representatives, from derogating from the protection already afforded aboriginal rights by the constitution.

The four aboriginal organizations participating in the First Ministers Conference appeared ready to accept the federal proposal, as did five provinces, (Newfoundland, Prince Edward Island, New Brunswick, Ontario, and Manitoba). While agreeing in principle, Quebec was unwilling to support a constitutional amendment.

British Columbia, Alberta, Saskatchewan and Nova Scotia all refused to support the federal proposal. British Columbia suggested that the constitution be amended to state that

the aboriginal peoples of Canada are entitled to rights of self-government within the context of the sovereign authority of the Parliament of Canada, and the Legislatures of provinces now provided for in the Constitutionof Canada, that are set out in agreements....(27)

Not surprisingly, in light of British Columbia's evident desire to limit aboriginal rights its suggestions did not receive much support.

Saskatchewan and Nova Scotia also presented their own amendments, proposing that the following sections be added to the Constitution Act, 1982:

") 35.01

The rights of the aboriginal peoples of Canada to self-government, within the context of the Canadian federation, that are set out in agreements in accordance with section $\mathbf{3 5 . 0 2}$ are hereby recognized and affirmed.

35.02

The rights of the aboriginal peoples of Canada to self-government may for the purposes of section 35.01 ... (are those) set out in agreements concluded with representatives of aboriginal people that are appropriate to the particular circumstances of those people (which)...

a) include a declaration to the effect that section 35.01 applies to those rights; and

b) are approved by an Act of Parliament and Acts of legislatures of any provinces in which those aboriginal people live.« (28) 
Saskatchewan and Nova Scotia were not willing to see a commitment to negotiate agreements with aboriginal representatives included in a constitutional amendment. Instead, it was suggested that this be set out in a political accord.

Had the five provinces which supported the federal proposal, and the four aboriginal groups agreed to the Saskatchewan-Nova Scotia amendments, these could then have become part of the constitution. (approval by seven of the ten provinces, with more than $50 \%$ of the population of Canada, is needed for any constitutional amendment). It is probable, however, that an amendment dealing with aboriginal rights would be seen by the federal government as also needing the support of the aboriginal organizations invited to participate at the constitutional conferences. However, a number of the provinces who had backed the federal government made their agreement to the Saskatchewan-Nova Scotia proposal conditional on aboriginal support. This support was only partially forthcoming. The Metis National Council and the Native Council of Canada agreed to the amendments, while the Inuit Committee on National Issues indicated that it would need to consult with the people it represented before giving a final answer. To allow time for this consultation, Prime Minister Mulroney stated that representatives of the federal and provincial governments, and of the aborignal groups, should meet again within six weeks. The Assembly of First Nations adamantly rejected the approach taken by Saskatchewan and Nova Scotia. In particular, the A.F.N. was opposed to the fact that no obligation to negotiate would be included in the Constitution and that, even if an agreement were reached, it would not take effect until both the federal and provincial government passed legislation to implement it. As the A.F.N. did not change its views with respect to the proposal, no agreement for constitutional change came out of the subsequent meeting held in 1985.

\section{The Common Law Doctrine of Aboriginal Rights}

The fact that efforts to amend the constitution so as to clarify section $35(1)$ have not been successful does not mean that the section as it is now worded is meaningless. Instead, the common law doctrine of aboriginal rights may be used to interpret section 35(1) (29). The recent Supreme Court of Canada case, Guerin et al v The Queen (30) confirms the existence of such a doctrine.

Before examining the common law meaning of aboriginal rights, it is necessary, however, to consider the effect of the work »existing". While some commentators have suggested that section 35(1) protects only those rights recognized by a court, or by the federal government as of April 17, 1982, (the date on which the Constitution was patriated), most have rejected such a narrow interpretation. It is argued instead that

the word existing should be read... as meaning "unextinguished" or "subsisting" thus excluding rights that had been terminated by lawful acts prior to the commencement date, but not requiring that any unextinguished rights have been fully recognized in Canadian law before that date. (31)

If this interpretation is correct, then it is necessary to consider whether, at common law, the right of self-government was seen as one aspect of aboriginal rights, and if so, whether it continued unextinguished until April 17, 1982.

According to the common law doctrine of aboriginal rights, »discovery « of North America by a European nation gave that nation ultimate sovereignty over the area discovered and claimed, but this did not automatically destroy all rights enjoyed by the original inhabitants. Specifically, aboriginal "property rights, customary law 
and governmental institutions « (32) were seen as surviving a European nation's acquisition of sovereignty.

There is an established line of cases, running from the 1823 decision of the American Supreme Court, Johnson and Graham's Leasee v McIntosh, (33) (relevant to Canadian Law because the Court based its characterization of aboriginal title in British policy in North America), to the 1984 Guerin decision, which recognize certain aboriginal property rights as having continued to exist after Britain acquired sovereignty over North America. Thus, Britain came to possess the ultimate fee simple to the land, and while only the Crown had the right to acquire full title to Indian territory, Indian tribes continued to have the right to possess and occupy their lands until these were surrendered to the Crown. Furthermore, the cases establish that aboriginal title flows from the historic fact of occupation and land use, not from executive or legislative acts of the government. (34)

Aboriginal laws and customs have also been recognized in a number of cases, and while these cases have all dealt with family law matters, there is no suggestion that customary law survived in this area only. (35)

Cases which recognize aboriginal property rights and customary law are relevant to the issue of self-government in a number of ways. First, several of the cases dealing with aboriginal title show the close tie between property rights and selfgovernment. For instance, the Johnson case states that Indians continued to control land use in unsurrendered areas. The ability to control a matter such as land use suggests the existence of methods of community decision making. Similiarly, in the Supreme Court of Canada decision in Calder v Attorney General of British Columbia, (36) aboriginal title is seen as flowing from the fact that »when settlers came, the Indians were here, organized into societies, and occupying the land as their forefathers had done for centuries.« (37) A people which form organized societies will have forms of government.

Obviously, there is also a link between customary law, and self-government. It might be argued that recognition of customary law is implicit recognition of a community's power to make and enforce laws.

The fact that aboriginal title and customary laws were not created by government acts, suggests that a right to self-government could also exist without having been created by the Crown. Similiarly, the fact that aboriginal title can exist along with ultimate title in the Crown, and that stwo different systems of civil and even criminal law may prevail « (38) emphasizes that aboriginal self-government could co-exist with the ultimate sovereignty of the Crown.

Finally, at least two cases give explicit recognition to a continued right of selfgovernment. Thus in Conolly v. Woolrich and Johnsonet al, (39) a case dealing with the validity of a custom marriage, the court held that although British common law had been transported to the colonies, this did not mean that

the territorial rights, political organization, such as it was, or the laws and useages of the Indian tribes, were abrogated; (Instead), far from being abolished, they were left in full force and were not even modified in the slightest degree, in regard to the civil rights of the natives. (40)

Even stronger support for the argument that a right to self-government was one aspect of native life which survived the British acquisition of North America, is found in Worcester v Georgia, (41) a decision of the American Supreme Court. The Court held that

a weaker power does not surrender its independence, its right to self-government, by associating with a stronger and taking its protection. (42) 
In the same decision, it is stated that

our history furnishes no example, from the first settlement of our country, of any attempt on the part of the Crown, to interfere with the internal affairs of the Indians, further than to keep out the agents of foreign powers... The King... never intruded into the interior of their affairs, nor interfered with their self-government, so far as respected only themselves. (43)

The court also pointed out that Indian acknowledgement of British sovereignty involved, practically no claim to their lands, no dominion over their persons. It merely bound the nation to the British Crown as a dependent ally, claiming the protection of a powerful friend and neighbour, without involving the surrender of their national character. (44)

In light of the common law doctrine of aboriginal rights, it seems reasonable to argue that a right to self-government is encompassed by the phrase "aboriginal rights" used in section 35(1) of the Constitution. In order to be protected by section 35(1), however, it must also be shown that the right to self-government was not extinguished before April 17, 1985. There are a number of factors which are most commonly cited to assert that any right to self-government which may once have existed has long since been extinguished.

First, it is sometimes suggested that an aboriginal right to self-government is incompatible with ultimate Canadian sovereignty. However, to accept this argument would be to deny the very essence of the common law approach to aboriginal rights; that is, that certain aboriginal rights survived the acquisition of sovereignty over North America by a European Crown.

It might also be argued that section 91(24) of the Constitution Act 1867, which allocates jurisdiction over »Indians and Lands Reserve the Indians« to the federal government leaves no room for inherent aboriginal powers of government. Yet, it should be remembered that sections 91 and 92 of the Constitution are primarily directed at defining federal and provincial powers in relation to each other. In this context, section 91(24) could be interpreted as recognizing the existence of a special relationship between Indians and the Crown, and as protecting this relationship from provincial interference. The section could even be seen as giving the federal government the responsibility of honoring and enhancing the rights flowing from a special relationship with the Crown.

The Indian Act has often been seen as legislation aimed at destroying the aboriginal way of life, including the ability of native communities to manage their own affairs. This interpretation of the Indian Act supports the contention that any inherent aboriginal right to self-government has been extinguished. However, this view of the impact of the Act is challenged by the recent decision of the Supreme Court of Canada in Guerin, to be discussed below.

The next section of this chapter first presents the generally accepted view of the Indian Act. Then, the approach found in Guerin is used to suggest that perhaps a right to self-government has survived the $A c t$.

\section{The Canadian Situation} Band Council Government

Britain's first "Indian policy « consisted chiefly of maintaining military alliances with friendly tribes. Not until after the war of 1812 did the British government come to view Indians as wards, to be »civilized « and assimilated, (45) a view which was continued in legislation passed in Canada. In 1876, all statutes dealing with Indians were combined into the first consolidated Indian Act (46) 
It is clear from this legislation that Canaca wanted Indians to adopt Euro-Canadian social norms and wished to suppress Indian values and native culture... The goal was to annihilate Indians as a separate and distinct ethnic group. (47)

-Not surprisingly, the wording of such legislation did not appear to recognize Indian nations as possessing any sovereign rights. Traditional political systems were replaced with an alien form of government, which was described at the time as "rdesigned to lead the Indian people by degrees to mingle with the white race in the ordinary avocations of life « and as »establishing a responsible (form of government) for an irresponsible (people)... to pave the way to the establishment of simple municipal institutions. « (48) The new form of government was alien not only because it purported to delegate jurisdiction rather than recognize inherent powers, but because it lacked the close connection with the whole life of the community that had characterized traditional systems. (49) The new form of government was rigorously imposed upon many Indian groups, such as the Six Nations' peoples near Brantford, Ontario.

Some bands, particularly in the west, did manage to resist the new style of government, and in 1980, approximately 210 bands still used traditional methods of choosing leaders. (50) However, such bands are not recognized by the federal government as having thus retained any aspect of sovereignty.

The present Indian Act (51), which still reflects the policies of the nineteenth century (52), continues the elected band council form of government first introduced in 1869. Band council powers are still very limited (53). In the 1960's, councils were characterized as »appendages ( $(54)$ which spent most of their time justifying the Department of Indian and Northern Affairs' policies and decisions, rather than making decisions of their own. (55). Since then, attempts have been made to give band councils more autonomy. For instance, the last Indian agent was removed in 1969; (56) since 1972, Indian Affairs has provided »core funding " (57) for council administrative costs; and recently, there has been a trend toward transferring delivery of certain services (although not the decision-making) from the Department to band councils (58). Despite these changes, however, band councils still "serve formally as extensions of the "DIA« (59). This is hardly surprising since the councils and the federal government are still operating within the confines of the Indian Act.

The system established in the Indian Act provides for the election of a chief and councillors by a majority of the adult members of the band (60). (Until 1951, only men were permitted to vote in council elections). The band council may pass bylaws on a number of matters, set out in section 81 of the Indian Act. If a bylaw is not disallowed by the Minister within forty days, it then comes into effect (61). Not only can these bylaws be overturned by the Minister, but they are subject to the Indian Act itself, and any regulations made under it by the Governor in Council or the Minister.

The federal government also controls the government process itself. The Governor in Council may pass regulations dealing with elections (62) and council meetings. The Minister may declare a chief or councillor unfit to hold office for a number of reasons including the fact that he has missed three consecutive council meetings without permission (63).

\section{Use of the Municipal Model.}

A band council, exercising authority over local matters, and possessing only those powers delegated by another level of government is, in many ways, similar to a municipal government. A municipal government is created by the province and is generally considered to have those powers which are specifically given, those which are necessarily implied by the express grant of authority, and those which are essential 
to carrying out the basic purposes of the municipal government (64). Since municipal governments have no inherent powers (65), the general principle is that any exercise of authority not granted by the province is ultra vires (66). Most municipal governments carry out the dual functions of legislating on local affairs and acting as an arm of the provincial government for some of its programs.(67) In fact, the trend in the last several decades has been toward greater integration between the provincial and municipal governments, with increased provincial funding and involvement.(68) Furthermore, even in the area of purely local matters there has been a tendency to remove certain matters from the jurisdiction of the municipal government, and place these with local boards or commissions.(69)

It has been said that

the attempt to impose the municipal type of local government upon Indian peoples has been the most consistently maintained element in federal Indian policy since confederation. (70)

In fact, bands do not even enjoy all the powers of the larger, more autonomous municipalities.(71) At best, band councils »are confined to matters with which a rural municipality might normally be concerned«.(72)

\section{Guerin et al $\vee$ The Queen.}

There is no doubt that the Indian Act appears to take a very restrictive view of Indian powers of government. At first appearance, it is hard to see the legislation as recognizing, or even leaving room for a continued right of self-government.

Since the Guerin decision, however, it is evident that the Indian Act must be read in light of the common law doctrine of aboriginal rights, and that this approach may lead to an interpretation quite different from that first suggested by the wording of the legislation. Thus, in Guerin section 18(1) of the $A c t$, which appears to give the federal government almost complete discretion as to whether a particular use of surrendered reserve land would be " for the use and benefit of the band $"$, is interpreted as placing restriction on the Crown, rather than on aboriginal rights. Section 18(1) is seen as

confirmation... of the historic responsibility which the Crown has undertaken to act on behalf of the Indians so as to protect their interests in transactions with third parties (73),

and as

an acknowledgement of an historic reality, namely that Indian Bands have a beneficial interest in their reserve and that the Crown has a responsibility to protect that interest... (74)

The Guerin decision also emphasizes the fact that aboriginal title did not originate with government acts. Once it is found that legislation such as the Indian Act is not creating a new right, but is simply recognizing one which already existed at common law, it is necessary to interpret the legislation in the way most compatible with the continuation of that right.

If these two aspects of the Guerin case are applied to the Indian Act and the right of self-government, it seems that the $A c t$ may not have extinguished that right. The right of self-government exists at common law, independent of any legislation. Therefore, band government provisions of the Indian Act must be interpreted in a manner compatible with the continued existence of that right. Thus, perhaps the Indian $A c t$ has merely recognized certain areas of aboriginal jurisdiction, rather than delegated new powers. Any jurisdiction not included in the Act has simply not been recognized, which is very different from extinguishment. Furthermore, those sections of 
the $A c t$ which appear to permit the federal government to disallow band by-laws, and to give the Crown a wide discretion over band monies can, since Guerin, be seen as merely regulatory, rather than as extinguishing the right of self-government.

\section{Proposals for Change}

The 1946 Joint Committee.

In 1946, in response to growing criticism of its Indian policy, the federal government appointed a special Joint Committee of the Senate and House of Commons to review the Indian Act and recommend changes. The Committee started from the assumption that the rights and responsibilities of Indians should be exactly the same as those of other Canadians; anything else would constitute discrimination (75). The paradox of this ethnocentric view is that the view itself expresses a most severe form of discrimination toward native peoples. Clearly, the Committee accepted the views of a well-known anthropologist who recommended that the government should abolish gradually but rapidly the separate political and social status of Indians...; to enfranchise them and merge them into the rest of the population on an equal footing. (76)

The Joint Committee presented its report in 1947, recommending that Indians should move from their present position as wards of the government to full citizenship, and that DINA of ficials should help Indians to achieve the rights and responsibilities attendant upon this new status. All Indians should be given the federal vote, and Indian women should be allowed to vote in band council elections. Band councils should become municipal governments and receive increased federal funding. Federal and provincial governments should work together to co-ordinate the provision of services to Indians.(77)

Although the Joint Committee probably felt that its report was very progressive, Indians at the time were proposing something entirely different. There were no Indian representatives on the Committee and a suggestion that Indian observers be invited to the Committee meetings was rejected. (78) Some Indian groups did, however, present briefs, and others sent written submissions. Indian suggestions ranged from greater independence in local government, to full sovereignty, with the majority supporting self-government for band councils.(79) It was argued that Indian nations had never relinquished their sovereignty and that self-government would be "a fundamental first step toward acknowledging the treaty relationship between Indians and the Crown

The recommendations for self-government were not reflected in either the Joint Committee's report, or the Indian Act of 1951.

\section{The Hawthorn Report.}

Nearly two decades after the appointment of the Joint Committee, the federal government established a Commission to study the social, educational, and economic situation of Indians of Canada and to offer recommendations where it appeared that benefits could be gained « (81).

The Commission's two volume Survey of Contempory Indians in Canada (82) (often referred to as the Hawthorn Report) was published in 1966.

According to the Hawthorn Report, The Department of Indian and Northern Affairs wished to see

the reserve community operating as a municipality within the appropriate municipalprovincial structure, receiving the same grants, carrying out the same functions, accepting the same responsibilities, and subject to the same controls and limitations as 
apply to non-Indian communities at equivalent social and economic levels of development. (83)

The continuation of band governments independent of the provinces and in a direct relationship with the federal government was sunacceptable« (84) to the Department.

The Hawthorn Commission agreed that some form of local government other than the present system should be extended to Indian communities. It recommended that for the purposes of grants from both federal and provincial governments, and shared cost programs, Indian governments should receive the same treatment as provincial municipalities (85). For other matters, however, it would be "premature" (86) to decide whether local Indian governments should be under federal or provincial jurisdiction. The Report warned that an immediate move toward placing such governments within the provincial sphere would be resisted by Indians (87) and that patterning Indian government on municipalities would not greatly increase Indian autonomy over local affairs (88). The Commission recommended that, ultimately, the choice as to the appropriate framework for local government be left to the Indians themselves (89).

While the Hawthorn Report recognized that many Indian bands should exercise greater control over their own affairs, it did not feel that increased autonomy would be reasonable for all Indian communities. The selection of those reserves with sufficient people and resources to make the establishment of local government appropriate should be done by a Local Government Bureau set up within the Department of Indian and Northern Affairs (90).

While the Hawthorn Report did use the phrase »self-government" it saw this as meaning only a restructured form of local government since

small numbers, geographic diffusion and the lack of economic and other resources preclude the possibility of an independant Indian nation-state being created to satisfy ... Indian aspirations (91).

Despite its restricted use of the term "self-government «, the Report did make two important advances. First, it characterized the federal government's control over Indian reserves as a form of sinternal colonialism « (92) which deprived Indians of any significant control over their own futures. Secondly, it rejected the idea that Indians would have to choose between special status and full citizenship. The recommendation that Indians should be viewed as having special rights was used by Indian leaders to resist the next major federal policy initiative (93).

\section{The 1969 White Paper}

In 1969, the federal government introduced a White Paper entitled $A$ Statement of the Government of Canada on Indian Policy (94). This came after fairly extensive consultations with Indian delegates who had made it clear that other issues should be dealt with before the Indian Act was amended.

Specifically, they demanded recognition of treaty obligations and aboriginal rights, the establishment of a Claims Commission, and a lifting of federal and provincial restrictions on hunting and fishing (95). The White Paper did not reflect the Indian position. Instead it recommended repealing the Indian Act, eliminating any special status for Indians, closing down the Department of Indian and Northern Affairs within five years, and turning band councils into municipal governments within provincial jurisdiction.(96) It also dismissed land claims based on aboriginal title, and downplayed the importance of treaty obligations.(97) The emphasis of the White Paper was on »equality in the sense that Indians were now to be like everyone el- 
se.(98) The objective of social progress for native peoples would be realized if there was equality in law. Special educational and social programs would be utilized to achieve equality in fact. Special legal status was seen as impeding progress toward equality of opportunity for Indians.

Indians quickly rejected the White Paper as a blatent attempt at assimilation.(99) Probably the best known response is the 1970 statement by the Indian Chiefs of Alberta, Citizen Plus, (100) which argued that the "special history, rights, and circumstances of Indian People« (101) required that a special status be recognized. This status was not to be in place of, but in addition to the rights enjoyed by other Canadians. Reaction against the White Paper was so strong that, in 1971 , its recommendations were withdrawn by the federal government (102).

\section{Optional Band Government Legislation.}

A few years later, the federal government drafted an Optional Band Government $A c t$ which would have transformed those bands which wished to come under the legislation into federal municipalities.(103) Each such band was to draw up a charter setting out the form of government to be used, its basic capacities, and its accountability to members.(104) Some of the authority given the Minister in the Indian Act would be delegated to the band level.(105) Later, the government considered changing the word »charter «, to »constitution«, hoping this would be more acceptable to Indians. However, although a constitution is usually taken to mean the "fundamental law « (106) of a sovereign nation, the federal proposal in no way recognized Indian sovereignty. Instead, whatever the terminology, any power possessed by Indian governments would be a delegation from Parliament rather than an exercise of inherent rights.(107) The proposed legislation was not welcomed by Indians.(108) For instance, the Union of Nova Scotia Indians described the approach as $»$ practically and philosophically unacceptable«, differing from the present system only in that sbands would be forced to give their consent to ministerial paternalism as the price of symbolic self-determination«.(109) This federal proposal was also later withdrawn.

Indian reaction to the Optional Band Government Act reflected the growing emphasis on self-government. The concept of aboriginal rights, which had first been used mainly in connection with land claims, was expanded throughout the 1970's to embrace the idea of an inherent, sovereign right to self-government.(110) Undoubtedly, two factors that served as catalysts in this development were first, the process of land claims in Arctic Canada where the Dene and Inuit emphasized that it was important for governmental institutions to be controled by native peoples to achieve their objectives, and second, the process of constitutional reform initiated by the Trudeau government which both provided a forum for native leaders which focused upon constitutional change and also drew the native peoples into a relationship of support for the federal Government; proposed changes provided that there was some constitutional recognition and protection of native rights.

\section{The 1983 Report on Indian Self-Government (Penner Report) Summary of Recommendations}

In 1982, a House of Commons Special Committee on Indian Self Government was appointed to make recommendations to Parliament regarding possible provisions of new legislation and improved administrative arrangements to apply to some or all Band governments on reserves, taking into account the various social, economic, administrative, political and demographic situations of Indian 
bands, and the views of Indian bands in regard to administrative or legal change. (111)

The Committee was made up of seven members of Parliament, one ex-officio member from the Assembly of First Nations, and two liason members; one from the Native Women's Associations of Canada, and the other representing the Native Council of Canada. The Committee released its Report (often referred to as the Penner Report) (112) in 1983.

The Report consistently uses the term »Indian First Nations «, defining a nation as a ")group of people with a common language, culture and history who identify with each other as belonging to a common political entity«.(113) The Report recognizes that, before contact with Europeans, these nations were self-governing.

Since Indians did not have a part in drafting the Constitution Act, 1867 which gave the federal government jurisdiction over "Indians and Lands Reserved for Indians», the first recommendation of the Penner Report is that

The federal government establish a new relationship with Indian First Nations and that an essential element of this relationship be Indian self government (114)

The Penner Report makes it clear that the new relationship should not be based upon the federal government's Optional Band Government draft legislation or simply upon further amendments to the Indian Act.(115) That is, a form of simple municipal government was seen as insufficient and inappropriate. The Report also notes that Indians would reject any attempt to weaken the trust relationship which exists between the federal government and Indian people (116).

The Committee sees bands, with a "newly defined « (117) membership, as the starting point for self-governing First Nations, with each band left to decide whether it would constitute an Indian government on its own, or whether it would join with other Indian communities (118). One method of determining membership would be to start with the existing band now registered under the Indian Act and any of its members reinstated by legislation. These people could then include others if they so wished. The initial members would establish criteria for membership, in accordance with international convenants on human rights, and would set up procedures for appealing membership decisions (119). A wnecessary first step to forming a government « would be to ensure that all members of the First Nation, "without regard to the restrictions of the Indian Act $\ll$ (120) were given a voice in forming that government.

Those Indians who do not become part of an Indian First Nation would still be eligible for federal programs designed for Indians (121) with representatives of such Indians meeting with Indian First Nation governments and federal and provincial governments to ensure that the interests of all Indians are protected.(122)

The Penner Report recommends that a clearly stated right to self-government be entrenched in the constitution (123). Until the provincial consent needed for such an amendment is attained, the Report proposes that the federal government should explore all other avenues, including the introduction of new legislation. It suggests that the terms of an »Indian First Nations Recognition Act« should be negotiated between the federal government and representatives of Indian First Nations. This suggested new legislation should establish the criteria for recognition as a First Nation government; for instance, that a significant majority of the members have clearly shown their support for the form of government, and that the membership code and appeal procedures are in accordance with international standards (124). The proposed Act should also specify the procedure for extending recognition to a government.

The Penner Report recommends that applications for recognition be considered 
by a panel appointed jointly by the federal government and Indian First Nations.(125) Because of the special relationship between Indians and the Crown, the Governor General should affirm federal recognition of First Nation Governments.(126) After recognition, the Indian First Nation government would negotiate with the federal government as to the jurisdiction it would exercise. The jurisdictional agreement could be renegotiated at a later date if this seemed appropriate.(127) Legislation would be needed to allow the federal government to enter into and ratify such agreements.(128)

The Penner Report recommends that the federal government should use its constitutional jurisdiction over »Indians and Lands Reserved for Indians « to "occupy « (129) areas of jurisdiction which but for section 91(24) of the Constitution Act 1867 would be within the provincial sphere. This would be done through federal enactment of legislation dealing with Indians in these subject areas. The federal government should then vacate to recognized First Nation governments vall areas of competence necessary to permit Indian First Nations to govern themselves effectively«.(130)

Indian First Nation governments could then exercise full legislative policy making powers in matters affecting Indian people and full control over the territory and resources within the boundaries of Indian land. (131) Specifically, the federal and provincial governments should acknowledge an Indian First Nations government's jurisdiction over education, family matters, use of land and resources, revenue raising (including taxation of individuals, transactions, land and resources within its boundaries), economic development, justice, and law enforcement.(132)

Obviously, jurisdictional disputes would arise among different levels of government. Therefore, the Penner Report recommends that a tribunal be established to deal with such disputes. The powers and format of the tribunal would be negotiated between the federal government and First Nation representatives.(133)

The Report predicts that ultimately claims settlements, Indian control and development of their land base, new arrangements for resource revenue sharing, and other long term entrenched financial arrangements (will) in due course provide Indian First Nation governments with assured funding. (134)

At present, however, band councils have little choice as to how they spend money received from Indian Affairs, since funds are tied to a particular program or service. The Penner Report recommends eliminating department control of budgeting and spending, with Indian First Nation governments accountable instead to their own members. First Nations should receive federal funding in the form of direct grants, with one single payment covering the cost of all government operations and services.(135) The amount of funding should be determined by a modified per capita formula« (136) agreed upon by the federal government and First Nation representatives. The funds should be provided through some mechanism similar to the transfer payments to the provinces.(137) Thus, the Penner Report sees the present transfer system of unconditional grants, through the equalization program, from the federal treasury to so-called have-not provinces, as being the model for fiscal arrangements for First Nation governments.

The Penner Report also recommends that funding should be provided to correct serious inadequacies in the infrastructure of Indian communities, and to cover the cost of preparing and applying for recognition.

The Penner Report suggests that, if national native organizations agreed, the fede- 
ral government should use the 345 million dollar Native Economic Development Fund to start a bank which could provide loans for economic development within Indian First Nations.(138) Also, the revenue now held in trust by the government for Indian bands should be transferred directly to First Nation governments. Capital funds should be transferred to a "trust management system« set up for the use and benefit of the Nation's members.(139)

The Penner Report describes land as $"$ a prerequisite for, and vital to selfgovernment " (140). Therefore, the federal government should give high priority to providing land to communities now without a reserve, and to settling land claims. A "just and effective « (141) claims process should be set out in legislation after negotiation between the federal government and First Nations. Where a settlement cannot be reached, a party should be able to take the claim to a "quasi-judicial ( (142) body for a decision. Indian First Nations would receive adequate funding for the preparation and presentation of claims. Finally, in the Penner Report's perspective, claims should not be seen as superseded by law (143) and the policy of extinguishment should be ended.(144)

The Report stresses that recognition of Indian First nation governments as a »distinct order of government within the Canadian federation « (145) involves an obligation on the part of the federal government "to act in the best interests of First Nations as those interests are percieved by Indians themselves«.(146) In order to carry out this obligation, the Report suggests that the federal government set up a Ministry of State for Indian First Nation Relations. This Ministry would, when so requested by First Nations, support the interest of Indians against competing interests of other individuals or governments (147). Secondly, an independent of ficer should be appointed to review official actions involving First Nation Governments and report its findings to Parliament.(148) Furthermore, the Penner Report recommends that federal funding be provided to establish an advocacy office to represent First Nations' interests in legal proceedings.(149)

As Indian First Nations increasingly control their own affairs, the Indian Affairs Program within the Department of Indian and Northern Affairs would no longer be needed. The Report suggests phasing it out within five years.(150).

\section{Commentary on the Penner Report}

(a) The Approach.

Despite its many recommendations, and the discussion on each, the Penner Report has been described as a

model, not a fully developed plan of how Indian bands and the federal governments structures could be reformed to bring about Indian self-government.(151) and as a "broadly conceived blueprint for reform « (152). In light of the Report's emphasis that changes should be negotiated between Indian representatives and the federal government, it is not surprising that many of the details of the move toward self-government are left open. While there are questions, some of them quite significant, which are left unanswered, the Penner Report does take an identifiable position.

The Penner Report recommendations do not reflect traditional government policy. Successive Indian Acts, based on nineteenth century ideas of assimilation and "civilization«, replaced traditional Indian political systems with a very restricted form of delegated authority. Protest against this loss of self-government is not new. Certain bands managed to retain their own methods of choosing leaders, and Indi- 
ans presenting briefs to the 1946 Joint Committee argued that Indian nations had never relinquished their sovereignty. The concept of the inherent right to self-government was implied in the Citizen Plus rejection of the 1969 White Paper (153), and in 1975, the Dene Nation demanded its own political jurisdiction within Canada (154) and its own political institutions. By the end of the last decade, the right to self-government was seen by Indians as a significant component of aboriginal rights (155).

This growing emphasis on self-government has not been reflected in federal Indian policy. As Indian demands have strengthened, Indian Affairs has recognized the need to allow band councils more authority, but only as a delegation of power from the federal government, not as a recognition of Indian sovereignty.

The Penner Report clearly accepts the Indian, rather than the federal, point of view. It acknowledges that, before the arrival of whites, Indians were self-governing nations and that Indians did not agree to part with their sovereignty. Equally importantly, the Report adopts terminology used by Indian witnesses, referring to "Indian First Nations «, and the recognition rather than the delegation of jurisdiction. Furthermore, the Report stresses the importance of the federal-Indian ralationship, emphasizing that it must be changed but not discarded.

\section{(b) Issues}

One important issue involved in any discussion of self-government is that of membership. At the same time that the Penner Committee was sitting, another House of Commons Committee was hearing evidence for its report, Indian Women and the Indian Act (156). Much of the testimony revolved around the question of membership. The Assembly of First Nations and other groups which represent status Indians insisted (as they have on other occasions) that the authority to determine membership is an inherent right of any self-governing nation, and that the federal government must not attempt any further interference with this right (157). Organizations representing native women and certain non-status groups have been equally adamant in their demands that the federal government rectify the situation it created with the Indian Act and reinstate those who have lost status through discriminatory sections of the $A c t$. Such groups have demanded that a membership code which prohibits discrimination on the basis of sex be a precondition for recognition of an Indian First Nation government (158).

One Commentator has suggested that the Penner Report "sides" (159) with the Assembly of First Nations. However, the Committee's recommendations on membership do not appear to be quite that clear cut. While the Report does not specifically endorse the idea of reinstating those who have lost their rights, it does suggest that the starting group for forming a First Nation could be those Indians in the community who are registered under the Indian Act, "plus those who might be reinstated by any changes in legislation « (160). This initial group, and any others which it wished to include, would then develop a membership code which "should be in accordance with the standards in international covenants concerned with human rights (161). Such covenants would prohibit differential treatment if based on certain grounds, including sex.

The Report goes on to state:

The Committee asserts as a principle that it is the rightful jurisdiction of each Indian First Nation to determine its membership according to its own particular criteria. The Committee recommends that each Indian First Nation adopt, as a necessary first step to forming a government, a procedure that will ensure that all people belonging 
to that First Nation have the opportunity of participation in the process of forming a government, without regard to the restrictions of the Indian Act (162)

Rather than »siding" with one group or another, the Penner Committee appears to have striven for a generally acceptable middle ground. The membership issue has been superceded by recent events. The first wave of legislative reform in respect of the Indian Act has now taken place, through Bill C-31 enacted June 12, 1985, whereby the membership provisions have been revised substantially, achieving »equality« for female band members in respect of rights.

Also related to the issue of membership is the question of the future of individuals or whole bands who do not become members of Indian First Nations. The Report suggests that the federal government consider using a general list as a means of providing special status « (163) for such people. Those on the general list would be eligible for federal Indian programs. However, a number of questions arise. For instance, would eligibility for the general list continue to be determined under the present Indian Act? Secondly, if First Nations take over the delivery of services to their members, how many of its present programs will the federal government continue for those on a general list? If the Indian Affairs Program were phased out, there would also be the question of which department would administer these remaining programs. Presumably, also, some provision would have to be made for the share of trust funds and reserve lands belonging to individuals or bands who do not become First Nation members. All these considerations can perhaps be reduced to one question; what relationship will be maintained between the federal government and those Indians on a general list?

A second major issue which must be addressed in a discussion of self-government is that of jurisdiction. The Penner Report is careful not to compare an Indian First Nation government to existing non-Indian governments. Instead, it refers to First Nation governments as a "distinct order of government within the Canadian federation « (164). Although the Report recommends that funding for Indian First Nation governments be patterned on federal-provincial fiscal arrangements, the Penner $R e$ port would create Indian First Nation governments with jurisdiction broader than that of provincial governments. The Report suggests that the federal government use its jurisdiction under section 91(24) of the Constitution Act 1867 to occupy areas which are in the provincial sphere and then "vacate« these and certain federal fields to leave room for Indian First Nations to exercise $»$ full legislative and policy-making powers in matters affecting Indian people« (165). Thus, an Indian Government could legislate in areas that would otherwise be provincial, as well as in federal areas.

It has been suggested that the Penner recommendations sthreaten to sever the ties between Indian Nations and the Canadien community« (166). One basic principle of a federal system is that two levels of government exist, with a division of powers such that each has a sdirect impact on the individual citizens and other legal persons within its area of competence (167). Thus, in Canada, both the federal and a provincial government can legislate for, and impose taxes on the same individuals, and both levels of government are directly accountable to the electorate (168).

The Penner Report, however, would create a system where in its own words, Legislative authority would...be with Indian governments, and the primary relationship of the Indian people involved with the federal government would be through these governments. (169)

This suggests that if an Indian First Nation decided to occupy all the areas of jurisdiction open to it, the federal government would have little direct contact with members of that Nation. Certainly, this would not be a federal system as we now know it. Per- 
haps there is even the danger that if a federal government could not legislate for, or tax, people belonging to a First Nation it might decide to remove their right to vote federally, thus forcing Indians to choose between being members of an Indian First Nation, or Canadian citizens (170). These speculations are, however, far removed from the intention of the Penner Report itself, which takes pains to state that Indian First Nation Governments exist within a federal system, and that

the exercise of political self-determination is a necessary step toward national unity. Canada would be strengthened not weakened as a result. (171)

A consideration of the jurisdiction of Indian First Nations also raises the question of whether the Canadian Charter of Rights and Freedoms (172) would apply. The Charter applies to both the federal and provincial governments, although section 33(1) provides that

Parliament or the legislature of a province may expressly declare, in an Act of Parliament or the legislature...that an Act, or a provision thereof shall operate notwithstanding a provision included in section 2 or sections 7 to 15 of this Charter.

This declaration would have to be reviewed every 5 years.

There is no indication that the Penner Committee itself saw Indian First Nation governments as exempt from Charter provisions. Yet, section 25 of the Charter states that

(t)he guarantee of certain rights and freedoms shall not be construed so as to abrogate or derogate from any aboriginal, treaty or other rights that pertain to the aboriginal people of Canada ...

and it has been suggested that if self-government were characterized as an aboriginal right, then the Charter could not be used to challenge decisions of Indian First Nations (173). If this were so, however, it would leave First Nation Governments with a wider latitude than either federal or provincial governments.

A third aspect of the Penner Report is the number of new offices which it advocates establishing; for instance, a Minstry of First Nation Relations, a tribunal for settling jurisdictional disputes, and independent officer to review government dealings with First Nations and a federally funded advocacy office for First Nations. At the same time, if the Penner recommendations were followed, the Department of Indian and Northern Affairs would be phased out within five years. The Report suggests that the Department should not simply be adapted to take over the new functions because of Indian mistrust of it (174).

Any new agencies or departments should, according to the Penner Report, remain fairly small, as a large staff would be unwieldy and would have to use a greater percentage of federal funding for First Nations on its own administrative costs (175). Furthermore, the larger and more bureaucratic a department became, the more difficult it would be for it to respond positively to change. The Penner Report also emphasizes that any new government body would have to avoid the attitude that it knows what is best for the new governments (176). Federal recognition of the right to self-government would be a major change and would involve some mistakes on both sides and some element of trial and error. However, solutions to initial problems should be worked out between the two levels of government, not imposed on one by the other.

\section{Federal Response to the Penner Report}

On March 5, 1984, DINA issued a brief $»$ Response to the Report on Indian SelfGovernment « (177). This begins with an acknowledgement that »Indian communi- 
ties were historically self-governing « (178) and an agreement to abandon the proposed Optional Band Government legislation. The federal response requires »further clarifications of the possible implications « (179) of the constitutional entrenchment of self-government, and places more stress than did the Penner Report on the need for consultation with the provinces. In the area of non-constitutional change, the federal government does agree to introduce legislation to establish a framework for those Indian First Nations that wish to govern themselves and their land in a way that is not possible under the Indian Act (180)

Since this would have to fit within the current Constitution, not all the powers referred to in the Penner Report could be included. The Department of Indian and Northern Affairs also states that it would be ready to sease current administrative constraints" (181) surrounding program planning and delivery. The Department would not be phased out until recognized Indian First Nation governments had taken over the programs now provided by Indian Affairs.

On June 27, 1984, Bill C-52, entitled »An Act relating to Self-Government for Indian Nations" was introduced in Parliament. It did not go beyond first reading. The preamble to the Bill re-affirmed the federal government's special responsibility toward Indians, recognized that Indian communities were whistorically selfgoverning " and stated that the federal government is committed to continuing and strenghtening Indian governments on lands reserved to Indians by providing for the recognition of the constitutions of Indian Nations and the powers of their governments.

Section 2 of the Bill defined an Indian Nation as one or more bands, or any Indian community sharing a common culture, history and language.

Under bill C-52, applications for recognition would have been decided upon by a seven member panel, appointed by the Governor in Council, on the Ministers' recommendation (182). three of the members would have had to be Indian and the Minister would have been required to consult with Indian representatives before recommending names for these three positions or that of chairman. Only the Governor in council could have overruled decisions of the panel (183). The right of overrule would have given the federal government the final say on deciding whether to recognize a band as a nation. This represents a divergence in approach from the Penner Report, which saw such decisions as being made jointly.

In order to be eligible for recognition under Bill C-52, an Indian First Nation would have been required to draw up a written constitution, consistent with "democratic principles « and the Canadian Charter of Rights and Freedom (184). Although, as mentioned earlier, an argument could perhaps be made that the Charter would not apply to First Nations Governments, in this Bill the federal government is clearly taking the position that Indian First Nation governments, like the federal and provincial governments, would be subject to the Charter. In Bill C-52, a First Nations's constitution would have included a membership code, which would have had to respect band membership rights acquired under the Indian Act, and to be in accordance with the Charter and international covenants on human rights. Government accountability, the protection of individual and collective rights, mechanisms for dealing with serious financial difficulties, a method for reviewing executive decisions, and a procedure for appealing membership decisions, were among the other matters to be dealt with in a constitution (185).

Members of the Indian First Nation applying for recognition would have to have voted in favour of such a move, in a referendum held in accordance with regulations made under the Act (186). In order to have been recognized, an Indian First Nation 
would also have been required to have negotiated a draft funding agreement with the federal government (187).

Furthermore, a band applying for recognition would have had to have been one for which land was held by the federal government (188). This is far more restrictive than the Penner Report for it would allow only bands now registered under the Indian $A c t$ to apply. The Report recommended that the federal government make it a priority to provide a land base for Indian communities presently without a reserve (189), and clearly saw such communities as having the right to apply for recognition.

Section 13 of Bill C-52 provided that a recognized Indian First Nation Government would have the capacity of a natural person and could enter into contracts, and acquire, hold and sell property.

Where a band was recognized as a nation, the rights, assets and liabilities of the band would have been vested in the Nation, and lands held for the benefit of the band would now be held by the Crown $)$ for the use and benefit of the Indian Nation, subject to the same terms and conditions « (190). Since the underlying title to Indian reserves is owned by the provincial Crown (191), the federal government could not by itself, turn over this ownership to First Nations.

The objects of an Indian First Nation government as set out in section 15 of the Bill would have been to act as a government authority within the Indian Nation's boundaries; to protect the individual and collective rights of members, and to promote their general welfare; to protect the cultural heritage of the Nation; and to use, manage, develop and regulate the First Nation's lands and resources.

Within its boundaries, an Indian First Nation government woúld have had legislative jurisdiction over education, taxation of real property, charges for public services, voter eligibility in and procedures for referenda to change its constitution, membership decisions, law enforcement, and other matters decided upon between the First Nation and the Minister at the time of recognition (192). These further matters could have included zoning and land-use planning; public health and safety; the environment and resources; the licencing of trades and businesses; public order and the administration of justice; family law; property rights; and local matters relating to the good government of the Indian Nation (193). Once an agreement for any of these further powers had been signed, the parties could then have agreed that the sections of the Indian Act dealing with those matters would no longer apply.

The executive powers of an Indian Nation within its boundaries would have included the management and administration of lands, the establishment of government institutions and offices, the provision of public works, community facilities, and social services, the economic development of the Nation, the operation of schools, and the undertaking of any of its legislative powers (194).

Bill C-52 would have allowed an Indian First Nation government to enter into agreements with other governments relating to the exercise of the Indian government's executive powers or regarding programs of the other government which affected Indian land (195).

Bill C-52 also dealt with the situation where members of a First Nation had aboriginal or treaty rights to land outside the First Nation's boundaries. The First Nation government could have passed legislation dealing with protection of wildlife and the environment and the regulation of hunting, trapping and fishing on those lands (196). This would have been very different from the present situation, where band councils are not given any authority over land off the reserve.

Section 28 of the Bill prohibited the passing of any legislation which conflicted with the Charter of Rights and Freedoms, or with international covenants on human 
rights. The reference to the Charter raises the question of whether First Nation governments could, like the federal and provincial governments, enact legislation expressly notwithstanding certain sections of the Charter. The reference to international human rights covenants raises a slightly different question. At present, although the Federal Government can sign international agreements that affect areas of provincial jurisdiction, only the provinces can pass legislation implementing such agreements (197). Without section 28, it might have been argued that a First Nation Government would be bound by international agreements falling within its sphere of jurisdiction only if these agreements were implemented by the First Nation government. It seems that section 28 would have precluded any such argument with regard to human rights covenants. Section 3 of Bill C-52 stated:

A law of an Indian Nation that is recognized, or any provision thereof may be disallowed by the Governor-in-Council at any time.

This right of disallowance is not necessarily inconsistent with the idea that First Nations would have jurisdiction and status analogous to that of the provinces. Section 55 of the Constitution Act, 1867 provides that Royal Assent can be withheld from federal bills. Section 90 states that a number of provisions of the $A c t$, including those dealing with the disallowance of acts "hall extend and apply to the legislatures of the several provinces «. Although in the early years of confederation, the federal government was fairly willing to use this power (over one hundred provincial acts were disallowed between 1867 and 1925) (198), in recent times the power has not been used (199). Thus, section 31 of Bill C-52 would not, in theory have given the federal government greater powers over First Nation legislation than over provincial acts. Instead, the question would have been whether, in practice, the federal government was willing to exercise the same restraint toward Indian legislation as it has come to show toward laws passed by the provinces. Bill C-52 would have allowed the Minister, with the approval of the Governor in Council, to enter into funding agreements with Indian First Nations. The Penner Report suggested that funding should be patterned on existing federal-provincial fiscal arrangements; however, section 55 of the Bill simply spoke of the provision of funds "over such period of time and subject to such terms and conditions as are specified in the agreement «. This very general language would presumably have allowed different nations to have very different funding arrangements with the federal government. Section 55 also provided that funding agreements could deal with the transfer to the First Nation of money held for the use and benefit of its members by the federal government, and section 56 would have required that Indian First Nation Governments submit a yearly report to the Minister, showing the application of federal funds.

Where the Minister was of the opinion that an Indian First Nation government had wabused its powers and (was) in serious financial difficulty or (was) unable to perform its functions« (200), Bill C-52 would have provided for the apppointment of an administrator to carry out the government's essential functions. The government could not then have exercised any of its powers until authorized to do so again. This provision, which would clearly have placed Indian First Nation governments in a subordinate position, appears to be a carry-over from the present situation where band council spending is closely controlled by the Department of Indian and Northern Affairs.

Bill C-52 would not have affected the application of the Indian Act to individuals or bands who did not become part of a First Nation (201). The Act would have continued to apply to a recognized First Nation until its first government was established and its constitution was in force (202). After that, the Indian Act, with necessary mo- 
difications, would still apply except as inconsistent with the Indian Nation's constitution, with Bill C-52, or with the powers of Indian Nations as set out in the Bill (203). Specifically, the Indian Act would still have applied for determining Indian status under that Act (204).

Bill C-52 also dealt with the application of general federal and provincial laws. Section 40 stated

subject to the terms of any agreement made pursuant to section 18,22, 23 or 25 and subject to the constitutions of Indian Nations, all federal laws of general application in force in Canada are applicable to and in respect of Indian Nations that are recognized, their members and their lands, except to the extent that such laws are inconsistent with this Act or any order, regulation or law made thereunder by the Governor in Council or the governments of the Indian Nations

and section 41 provided that

provincial laws of general application do not apply to or in respect of Indian Nations that are recognized, their members or their lands to the extent that the provincial laws are inconsistent with or in conflict with the terms of any treaty, any agreement made pursuant to section 18,22, 23 or 25, the constitutions of the Indian Nations, this or any other Act of Parliament or any order, regulation or law made under this Act.

These provisions highlighted the fact that an Indian First Nation Government would be a different »order of government « from those which were now know, and that members of an Indian Nation could be subject to federal, provincial and First Nation laws.

Bill C-52 did not become law, and it will be for the Conservative Government of Prime Minister Brian Mulroney to consider whether to introduce legislation in response to the Penner Report.

\section{Local Government under the James Bay Agreement.}

Section 9 of the James Bay and Northern Quebec Agreement required the federal government to introduce special legislation dealing with Indian local government over designated land. On June 8, 1984, the Cree-Naskapi (of Quebec) Act(205) was passed.

This $A c t$ provides that »except for the purposes of determining which of the Cree beneficiaries and Naskapi beneficiaries are Indian within the meaning of the Indian Act «, the Indian Act does not apply to the Cree and Naskapi bands or to the designated land (206). The new $A c t$ prevails over any inconsistent federal legislation, and over any provincial legislation which is inconsistent with or conflicts with the CreeNaskapi Act or which provides for a matter already dealt with in the Act (207).

Part II of the Cree-Naskapi Act deals with local government. Certain listed bands are to incorporate, with the rights, assets and liabilities of the old bands vesting in the new bands. Sections 17 to 20.1 deal with membership, and section 21 sets out the objects and powers of the newly incorporated bands. These include acting as the local government authority over designated land; using, administering and regulating land and natural resources and controlling the rights of disposition; managing and administering band money and other assets; promoting the general welfare of band members; carrying out community development programs; and preserving Indian culture. Finally, the new band is to exercise the powers and carry out the duties set out in any act of Parliament or federal regulations, or in the James Bay Agreement.

Section 22(1) of the Cree-Naskapi Act states that a band has the capacity of a natural person but subsection (2) prohibits the band from engaging in any commercial ac- 
tivity other than administering or managing its lands, natural resources and buildings, or providing public services.

Section 45(1) provides that a band council may pass bylaws »of a local nature for the good government « of the band, and for its general welfare. The matters which a council may deal with include band administration and management; public health and safety; public order; protection of the environment and natural resources; provision of local services; transportation; the operation of businesses and trades; parks and recreation; and taxation, for local purposes, other than by income tax, of interests in the designated lands or occupants and tenants of such lands. The band cannot, however, tax Canada's or Quebec's interests in those lands, or their occupation or tenancy.

Section 46 and 47 of the Cree-Naskapi Act allow for planning and zoning bylaws, and section 48 deals with hunting and fishing bylaws.

Section 53 requires a band council to send the Minister a copy of a bylaw within thirty days of its coming into force, but failure to do so does not affect the bylaw's validity.

Part IV of the Cree-Naskapi Act deals with financial administration. Section 90(1) requires a band to adopt a budget for each fiscal year and section $90(5)$ states that band money cannot be spent unless the expenditure is authorized by a bylaw or resolution, and the band treasurer certifies that the money is available. Sections 91 to 94 deal with the keeping of accounts and a yearly audit. Section 100 provides that where the Minister is of the opinion that sthe financial affairs of a band are in serious disorder«, he may give written notice to the band of his intention to appoint an administrator. After the appointment, band money cannot be spent without consent from the administrator.

Part VI of the Cree-Naskapi Act deals with land ownership. Section 109(1) states that Québec retains »basic ownership« of the lands over which band local government is exercised. Section 109(2) provides that, subject to this Act, the exclusive use and benefit of the land and natural resources lies with the band, which can administer, manage and use the lands and resources as if it were the owner.

Section 113 states that Quebec owns all the mineral rights and subsurface rights in the land. However, the right to exploit minerals or other subsurface materials cannot be granted without permission from the band in question, and the payment of compensation.

When introducing the Cree-Naskapi Act in Parliament, the Minister of the Department of Indian and Northern Affairs stated that self-government had been a »central theme« (208) during negotiations, but that the Grand Council of the Crees sexplicitly rejected assumptions that this proposal would be used as a model for selfgovernment legislation « (209). It is unlikely that Indian First Nations would see the $A c t$ as an appropriate model, for although it does give the bands a much greater say in resource development, and greater powers of local government, the authority exercised by the new band councils is delegated from the federal government. The form of band local government is that of a municipal government.

\section{The American Situation}

Having examined the aboriginal right to self-government in the Canadian context, it is interesting to consider the American situation. The common law approach to aborginal rights in Canada has grown out of early American cases, although since that time the American and Canadian law in this area has diverged. Despite the different approaches, however, one writer has suggested that, in both countries, the aim 
has been to assimilate aboriginal peoples, although different methods have been used (210).

\section{American Indian Legislation.}

In 1790, the American government passed its first Indian Trade and Intercourse Act (211) which extended federal jurisdiction to non-Indians on Indian land. This, and other Trade and Intercourse Acts (the last was passed in 1834), although ostensibly designed to protect Indians from white intruders, also significantly decreased Indian sovereignty (212).

In 1830 the Indian Removal Act (213) forced tribes to move westward, leaving the land they had traditionally occupied open for white settlement. However, tribal systems of government survived the move, and continued for some time to exercise considerable authority within Indian territory. Until 1885, Indian courts retained full criminal jurisdiction on reservations. The Major Crimes Act (214) of that year transferred jurisdiction over more serious crimes committed on a reservation to the federal courts.

1887 saw the introduction of the General Allotment Act (215), designed to end communal land holding and reduce the amount of Indian territory. Certain portions of Indian lands were labelled »surplus" and sold to settlers, with the proceeds held in trust for the Indians.

In the 1890's, legislation was passed which restricted the jurisdiction of a number of tribes by allotting tribal lands, abolishing tribal courts, and stating that the laws of the Indian governments could not be enforced in federal courts (216).

The next major piece of Indian legislation, the Indian Reorganization Act (217), was passed in 1934. The Act gave tribes the choice of whether or not to accept a »restructured form of tribal government « (218) involving a written constitution and bylaws, and open elections. Over two thirds of the tribes voted to accept the new system. The Bureau of Indian Affairs interpreted the $A c t$ broadly as giving the Bureau the authority to veto or ratify constitutions and bylaws, and even to veto tribal ordinances. However, the Act did increase slightly tribal government powers (219), establish economic development programs (220) and end the policy of the Allotment $A c t$, returning unsold "surplus « to tribal ownership (221).

The 1948 Assimilative Crimes Act (222) provided that federal courts could apply state criminal laws to areas under federal control. Although this was not specifically "Indian legislation", the $A c t$ was interpreted so as to allow the application of state laws to reserves in certain circumstances (223).

In 1953, Congress passed Public Law 280 (224) permitting states to extend their jurisdiction over certain Indian lands. Not until 1968 was a state required to obtain a tribe's consent before doing so (225).

1953 also saw the introduction of a new policy under which the Bureau of Indian Affairs drew up lists of those tribes which it felt were sufficiently developed, in economic terms, so as not to need federal services. Federal recognition of such tribes was withdrawn, as was their immunity from state taxes (226). This policy, which proved disastrous, was formally ended in 1968.

Also in 1968, the Indian Civil Rights Act (227) was introduced. This legislation restricted the jurisdiction of Indian courts to offences with a maximum penalty of a 500 fine, or six months in jail. The $1968 \mathrm{Act}$ also required tribal governments to proide many of the individual rights found in the American Constitution. Allegations of failure to do so could be brought in the federal courts (228).

The Indian Self Determination and Education Act (229) of 1975 was designed to 
increase Indian participation in the delivery of federal services (230). The Act stated that the Secretary of the Interior shall

upon the request of any Indian tribe... enter into a contract or contracts with any tribal organization of any such Indian tribes to plan, conduct, and administer prorams or portions thereof, provided in (any existing Indian legislation)...4 (231)

The Secretary may refuse only if he is of the opinion that such a contract would not result in the proper provision of the service, or in the adequate protection of tribal resources.

\section{American Case Law}

The extent to which American tribes are viewed as having retained sovereignty is determined not only by legislation but by a series of cases which deal with the issue.

In 1831, in Cherokee Nation v Georgia (232) the American Supreme Court held that Indian nations were »domestic dependent nations «(233) rather than foreign states. The next year, in Worcester v Georgia (234) the same court characterized Indian nations as

distinct political communities having territorial boundaries within which their authority is exclusive, and having a right to all the lands within those boundaries. (235) Since the Cherokee Nation had retained its inherent sovereignty within its boundaries, the court held that the state could not impose its laws over that territory.

In Ex Parte Crow Dog (236) it was held that when one Indian committed a crime against another on Indian territory, only Indian courts could punish the wrong-doer. Public reaction to this case (it was felt that a murderer had been treated too leniently) led to the 1885 Major Crimes $A c t$, which reduced the criminal jurisdiction of Indian courts. The validity of this Act was challenged in US $\vee$ Kanga (237). The application of federal law to Indian territory was upheld on the gorund that a guardian-ward relationship existed, with Indian governments dependent on Congress for their political power.

The next major case in this area occurred in 1903. In Lone Wolf $v$ Hitchcock (238), the Supreme Court refused to review a purchase of Indian land by the American goernment, although the consent required by a treaty had not been obtained. The Court held that Congress possessed a plenary power over Indian affairs, and that its decision in this matter was a political one, not subject to judicial review.

In 1956 in Iron Crow v Oglala Sioux Tribe (239) the American Court of Appeal upheld a tribe's right to make and enforce laws. The Court also stated that a tribe possesses the inherent rights of a sovereign government except to the extent that these have been restricted by Congress.

In the 1975 case of US v Mazurie (240) the American Supreme Court described tribes as "unique aggregations possessing attributes of sovereignty over both their members and ... their territory «(241).

The same year, it was held that a county could not use Public Law 280 to impose its zoning bylaw on a reserve as this would be $»$ nconsistent with tribal selfdetermination and autonomy«(242).

\section{Summary}

The case law reveals the courts' willingness to uphold federal intervention in Indian government, justifying such intervention on the grounds that Congress has plenary power over Indian affairs, that a ward-guardian relationship exists between Indians and the American government, or that a particular action was political and therefore not open to review (243). Yet, courts have characterized the jurisdiction still exerci- 
sed by tribal governments as flowing from retained sovereignty rather than as delegated by Congress. American tribes have been described as possessing " theoretical sovereignty and some self-governing powers « 244 ). These powers include determining membership, regulating probate and family matters, deciding whether to lease or surrender Indian land, allotting land to members, taxing those living on the reserve, controlling tribe assets, establishing tribal courts, and passing "municipal-type" laws (245). The Bureau of Indian Affairs still has significant powers, however. The Commissioner of the Bureau is responsible for $n$ the management of all Indian affairs, and (for) all matters arising out of Indian relations « (246). This power can be used to disallow tribe ordinances (247). The Commissioner also controls money appropriated for the »benefit, care, and assistance of the Indians; « (248) and because of the size of the Bureau, a substantial amount of this money goes to administration (249). However, although Indian tribes in the United States are not fully selfgoverning, it appears that »as tribes adopt more and more American style governmental institutions ... the Bureau seems willing to permit a substantial degree of tribal government (250).

\section{Conclusion}

Indian dissatisfaction in Canada with their lack of self-control over their own lives is not new. Within the past decade, however, Indian demands and aspirations have developed within the concept of aboriginal rights, one aspect of which is selfgovernment. Although the question of how self-government might be achieved within the Canadian federation is very complex, at least some of the theoretical ground work has been laid. For instance, it seems that any proposal based on the mere delegation of authority, rather than the recognition of certain inherent jurisdiction, would be rejected by most Indian leaders. By endorsing the concept of Indian First Nation governments existing within the Canadian federation, yet acting autonomously in a wide range of matters, the Penner Report has given support to Indian demands for self-government based upon an inherent right of sovereignty.

\section{Footnotes}

1 Kickingbird, Indian Sovereignty, Institute for The Development of Indian Law, Washington, 1978, at p. 5.

2 Mason, "Candian and United States Approaches to Indian Sovereignty", (1983) 21 Osgoode Hall L.J. 422, at p. 423.

3 Bartlett, The Indian Act of Canada, University of Saskatchewan Native Law Centre, Saskatoon, 1980 , at p. 3.

$4 \mathrm{Ibid}$, at p. 13, and Mason supra, footnote 2.

5 Littlebear, Indian Self-Government and Federal Indian Policy, University of Saskatchewan Native Law Centre, Saskatoon, 1983, at p. 2.

6 Policy Development Group, The Government of Aboriginal Peoples, Ottawa, 1983, at p. 112.

7 Mason, supra, footnote 2.

8 Ibid, at p. 425.

9 R.S.C. 1970, App.I.

10 Mason, supra, footnote 2, at pp. 426-436 and Policy Development Group, supra, footnote 6, at p. 105.

1130 and 31 Vict., c.3.

12 Policy Development Group, supra, footnote 6, at p. 105.

13 Zlotkin, Unfinished Business: Aboriginal People and the 1983 Constitutional Conference, Institue of Intergovernmental Affairs, Queen's University, Kingston, 1983, at p-55.

14 Ibid at p.57. 
15 The following subsection was added to section 35 of the Constitution Act, 1982: (4) Notwithstanding any other provision of this Act, the aboriginal and treaty rights referred to in subsection (1) are guaranteed equally to male and female persons.

16 Federal Provincial Conference of First Ministers on Aboriginal Constitutional Matters (Verbatim Transcript), Ottawa, 1983. Appendix.

17 Federal Provincial Conference of First Ministers on Aboriginal Constitutional Matters (Verbatim Transcript), Ottawa, 1984, at p-15.

18 Zlotkin, "The 1983 and 1984 Constitutional Conferences: Only the beginning", (1984) I C.N.L.R.I, at $\mathrm{p}-13$.

19 Jbid, at p-14

20 lbid, at $\mathrm{p}-15$.

21 "Proposed 1985 Accord Relating to the Aboriginal Peoples of Canada«, Document 800-20/041, First Ministers Conference on Aboriginal Constitutional Matters, Ottawa, 1985.

22 Ibid, at p-1.

23 Ibid.

24 Ibid at $\mathrm{p}-2$.

25 Ibid at $\mathrm{p}-3$.

26 Ibid at $\mathrm{p}-4$.

27 "British Columbia Proposak, Document 800-20/035. First Ministers Conference on Aboriginal Constitutional Matters, Ottawa, 1985.

28 "Saskatchewan, Nova Scotia Proposal«, First Ministers Conference on Aboriginal Constitutional Matters, Ottawa, 1985.

29 Slattery, »The Hidden Constitution - Aboriginal Rights in Canadau, (1984), 32 Am. J. Comp-Law, 361 , at p-366.

30 (1984), 55 N.R. 161.

31 Slattery, supra footnote 29 , at p-382.

32 Ibid, p-306.

33 (1823), 8 Wheaton 543; U.S. Rep. 240.

34 For a fuller discussion see chapter 1 to 6, Cumming (ed), Native Peoples ${ }^{2}$ Rights, EmondMontgomery Ltd., Toronto, 1986.

35 For a fuller discussion see chapter 15, Cumming (ed.), Native Peoples' Rights, Emond-Montgomery Ltd., Toronto, 1986.

36 (1973), 34 D.L.R. (3d) 145.

37 lbid, at p-156.

38 (1867), 17 R.J.R.Q., 75, at p-95.

39 Ibid.

40 Ibid at p-84.

41 (1982), 6 Pitus 515; 31 U.S. Rep. 350.

42 Ibid, at p-560.

43 Ibid, at p.546.

44 Ibid, at p.551.

45 Leslie and Maguire, The Historical Development of the Indian Act (2nd ed.), D.I.N.A. Treaties \& Historical Research Centre, Ottawa, 1978, at p. 53.

4639 Vict, c. 18.

47 Johnson, Helping Indians to Help Themselves - A Committee to Investigate Itself. The 195I Indian Act Consultation Process, D.I.N.A., Treaties and Historical Research Centre, Ottawa, 1984, at p. 7.

481871 Sessional Paper No. 3, quoted in Bartlett, Supra, footnote 3, at p. 14.

49 Tennant, Supra footnote 13, at 211.

50 Indian Conditions: A Survey, Department of Indian Affairs and Northern Development, Ottawa, 1980, at p. 84.

51 R.S.C. 1970, 1-6.

52 Bartlett, Supra, footnote 3, at p. 17.

53 Mason, Supra, footnote 2, at p. 430.

54 Hawthorn, (ed) $A$ Survey of The Contemporary Indians of Canada, Indian Affairs Branch, Ottawa, 1966 , ai p. 195. 
55 Ibid, at p. 192.

56 Supra, footnote 60 , at p. 82 .

57 Ibid.

58 lbid.

59 Policy Development Group, Supra, footnote 6 introduction.

60 Indian Act, section 74.

61 Section 82.

62 Sections 74 and 76.

63 Section 78(2).

64 Rogers, The Law of Canadian Municipal Corporation, Volume 1, Carswell Co. Ltd., Toronto, 1971, at p. 309.

$65 \mathrm{Ibid}$, at p. 310.

66 Ibid, at p. 309.

67 Ibid at p. 2.

68 Hawthorn, supra, footnote 64, at p. 287.

69. Ibid.

70 Tennant, supra, footnote 13, at p. 211 .

71 Mason, supra, footnote 2, at p. 447.

72 Bartlett, supra, footnote 3, at p. 20.

73 Guerin et al v Canada (1984) 55 N.R. 161, at p-175.

74 Ibid, at p-85.

75 Johnson, supra, footnote 57, at p. 17.

76 Diamond Jenness, quoted in Johnson, supra, footnote 57, at p. 24.

77 Johnson, supra, footnote 57, at p. 46.

78 Ibid, p. 15.

79 Ibid, p. 26.

80 Ibid, p. 31.

81 Hawthorn, supra, footnote 64, introduction.

82 Hawthorn, supra, footnote 64.

83 Ibid, at p. 293.

84 Ibid.

85 Ibid, at p. 303.

86 Ibid, at p. 229.

87 Ibid, at p. 299.

88 Ibid, at p. 300.

$89 \mathrm{Ibid}$, at p. 299.

$90 \mathrm{Ibid}$, at p. 298.

91 Ibid, at p. 263.

92 Ibid, at p. 292.

93 Weaver, Making Canadian Indian Policy, the Hidden Agenda, 1968-70, University of Toronto Press, 1981, at p. 173.

94 Department of Indian Affairs \& Northern Development, Queen's Printer, Ottawa, 1969.

95 Weaver, supra footnote 101, at p. 172.

96 Weaver, „A Commentary on the Penner Report«, (1984) 2 Canadian Public Policy, 215, at p. 216.

97 Banting and Simeon, (eds) And No One Cheered, Methuen Publications, Toronto, 1983, at p. 302, and Weaver, supra, footnote 103, at p. 6.

98 Weaver, supra, footnote 101, at p. 5.

99 Cardinal, The Unjust Society, M. G. Hurtig Ltd., Publishers, Edmonton, 1969, p. 1.

100 Indian Chiefs of Alberta, "Citizens Plus«, The Only Good Indian, (ed) Waubageshig, New Press, . Toronto, 1970.

101 lbid, p. 9.

102 Weaver, supro, footnote 101 , at p. 5.

103 Tenant, supra, footnote 13, at p. 212.

104 Littlebear, supra, footnote 5, at p. 4.

105 Ibid. 
106 Ibid, at p. 8.

$107 \mathrm{Jbid}$, at p. 3.

108 Tenant, supra, footnote 13, at p. 212.

109 "Proposal of The Union of Nova Scotia Indians for the Revision of the Indian Act«, (1979) 3 C.N.L.R. 1, at p.4.

110 Weaver, supra, footnote 104, at p. 216.

111 Special Committee on Indian Self-Government, Indian Self-Government in Canada, Queen's Printer, Ottawa, 1983, at p. 3.

112 Ibid.

$113 \mathrm{Ibid}$, at p. 12.

114 Ibid, at p. 41.

$115 \mathrm{Ibid}$, at p. 47

$116 \mathrm{Ibid}$, at p. 24.

$117 \mathrm{Ibid}$, at p. 54.

118 Ibid.

$119 \mathrm{Ibid}$, at p. 55.

120 Ibid.

$121 \mathrm{Ibid}$, at p. 56.

122 Ibid, at p. 68.

$123 \mathrm{Ibid}$, at p. 44.

$124 \mathrm{Ibid}$, at p. 57.

$125 \mathrm{Ibid}$, at p. 61.

126 Ibid.

$127 \mathrm{Ibid}$, at p. 62.

$128 \mathrm{Ibid}$, at p. 57.

$129 \mathrm{Ibid}$, at p. 58.

$130 \mathrm{Ibid}$, at p. 59.

131 Ibid, at p. 64.

132 Ibid.

133 Ibid, at p. 67.

134 Ibid, qt p. 97.

135 Ibid, at p. 98.

136 Ibid, at p. 100 .

137 Ibid, at p. 101.

$138 \mathrm{Ibid}$, at p. 76.

$139 \mathrm{Ibid}$, at p. 129.

140 Ibid, at p. 105.

$141 \mathrm{Ibid}$, at p. 113

$142 \mathrm{Ibid}$, at p. 115.

143 Ibid.

$144 \mathrm{Ibid}$, at p. 116.

$145 \mathrm{Ibid}$, at p. 121.

$146 \mathrm{Ibid}$, at p. 122.

147 Ibid.

$148 \mathrm{Ibid}$, at p. 124.

$149 \mathrm{Ibid}$, at p. 125.

$150 \mathrm{Ibid}$, at p. 134.

151 Weaver, supra, footnote 104, at p. 215.

152 Ibid, at p. 219.

153 Ibid, at p. 216.

154 Erasmus »We The Dene«, in The Dene Nation - The Colony Within (ed) Watkins, University of Toronto Press, Toronto, 1977, at p. 180.

155 Weaver, supra, footnote 1 at p. 216.

156 Standing Committee of Indian Affairs and Northern Development, Indian Women and the Indian Act, Minutes of Proceedings \& Evidence, Queen's Printer, Ottawa, 1982. 
157 Ibid.

$158 \mathrm{lbid}$. Since these hearings, the membership provisions of the Indian Act have been changed.

159 Tennant, supra, footnote 13, at 214.

160 Special Committee on Indian Self-Government, supra, footnote 119, at p. 55.

161 lbid.

162 lbid.

163 Ibid, at p. 56.

164 lbid, at p. 121

165 Ibid, at p. 59.

166 Gibbons and Ponting, "The Paradoxical Nature of The Penner Report«, (1984) 2 Canadian Public Policy«04, 221, at p. 222.

167 Sawyer, "Modern Federalism «, in Constitutional Law of Canada, (ed) Magnet, Carswell Co. Ltd., Toronto, 1983, at p. 1.

168 Gibbons and Ponting, supra, footnote 174, at p. 223.

169 Special Committee on Indian Self-Government, supra, footnote 119, at p. 56.

170 lbid, at p. 224.

171 Special Committee on Indian Self-Government, supra, footnote 119, at p. 42.

172 Constitution Act, 1982, Sch. B., Canada Act 1982 c.11 U.K.

173 Sanders, "The Rights of the Aboriginal Peoples of Canada", (1983) 61 Can. B. Rev.«, 314.

174 Special Committee on Indian Self-Government, supra, footnote 119, at p. 134.

175 Ibid, at p. 60.

176 lbid.

177 "Response of the Government to the Report of the Special Committee on Indian Self-Government«, D.I.N.A., Ottawa, 1984.

178 lbid, at p. 1.

179 Ibid, at p. 2.

180 Ibid, at p. 3.

181 lbid, at p. 7.

182 Bill C-52, Section 42.

183 Ibid, Section 49 (2).

184 Ibid, Section 6 (a).

$185 \mathrm{lbid}$, Section 6 (b).

$186 \mathrm{Jbid}$, Section 3 (1) (b).

187 Ibid, Section 6 (c).

188 Ibid, Section 6 (e).

189 Special Committee on Indian Self-Government, supra footnote 119, at p. 112.

190 Bill C-52, Section 37.

191 St. Catherine's Milling and Lumber Co. v. The Queen, (1889), 14 App. Cas. 46.

192 Bill C-52, Section 16.

193 Bill C-52, Section 19.

194 ill C-52, Section 17.

195 Bill C-52, Section 17 (2).

196 Bill C-52, Section 23.

197 Castel, International Law, University of Toronto Press, Toronto, 1965, at p. 852.

198 La Forest, Disallowance and Reservation of Provincial Legislation, Department of Justice, Ottawa, 1965, Appendix $A$.

199 Ibid.

200 Bill C-52, Section 26.

201 Bill C-52, Section 33.

202 Bill C-52, Sections 9 and 34.

203 ill C-52, Section 35.

204 Bill C-52, Section 36.

205 House of Commons Bills, 1984, Bill C-46.

206 Ibid, Section 5.

$207 \mathrm{Ibid}$, Sections 3 and 4. 
208 Munroe, "Statement for Second Reading of The Cree/Naskapi Act«, D.I.N.A., Ottawa, 1984, at p. 2.

209 Ibid, at p. 3.

210 Mason, supra, footnote 2.

2111 Stat. 137 (1790).

212 Kickingbird, supra, footnote 1, at p. 18.

2134 Stat. 411 (1830).

21423 Stat. 385 (1885).

21524 Stat. 388 (1887).

216 Kickingbird, supra, footnote 1, at p. 21.

21748 Stat. 984 (1934).

218 Grossman, The Sovereignty of American Indian Tribes: A Matter of Legal History, Minnesota Civil Liberties Union Federation, 1979, at 11.

219 Mason, supra, footnote 2, at p. 453.

220 Kickingbird, supra, footnote 1, at p. 21.

221 Rieber, The United States Federal Government - Indian Relationship, Trusteeship and Local Government, Jesse Rieber and Associates, Winnepeg, 1977, at p. 68.

22218 U.S.C. 13, (1948).

223 United States Department of the Interior, Federal Indian Law, Association on American Indian Affairs Inc., New York, 1966, at p. 8.

22467 Stat. 588 (1953).

225 Grossman, supra, footnote 22, at p. 14.

$226 \mathrm{Ibid}$, at p. 13.

22782 Stat. 77, (1968).

228 Grossmann, supra, footnote 22, at p. 15.

22925 U.S.C. s. 450 (176).

230 Quoted in Mason, supra, footnote 2, at p. 456.

231 Quoted in Mason, Ibid.

23230 U.S. 1 (1831).

233 Ibid, headnote.

23431 U.S. 515 (1832).

$235 \mathrm{Ibid}$, at p. 577.

236109 U.S. 556 (1883).

237118 U.S. 375 (1886).

238187 U.S. 553 (1903).

239231 F. 2d 89 (1956).

240419 U.S. 544 (1975).

241 Ibid, at p. 557.

242 Santa Rosa Band of Indians v. Kings County, 532 F. 2d 655 (1975).

243 Kickingbird, supra, footnote 1, at p. 17.

244 Mason, supra, footnote 2, at p. 424.

245 Ibid. at p. 458.

24625 U.S.C. 52 (1976).

247 Mason, supra, footnote 2, at p. 459.

24825 U.S.C. s. 13 (1976).

249 Mason, supra, footnote 2, at p. 455.

$250 \mathrm{Ibid}$, at p. 461. 